\title{
University Libraries Section at Midwinter
}

\author{
A wrap-up of activities
}

by Jennifer Evans

$T^{n+4}$ he University Libraries Section (ULS) Executive Committee, chaired by Elaine Didier (Oakland University), met twice during Midwinter and reviewed two packed agendas, including reports from many section committee chairs and liaisons. Action taken included approving the name change of the Librarians in Higher Education and Campus Administration Discussion Group to the Campus Administration and Leadership Discussion Group. This discussion group, newly revitalized by Mem Stahley (University of Central Florida), will have a planning committee appointed by the section chair in the future. Discussions will continue to be held at Midwinter, and all those interested are encouraged to attend.

The Executive Committee also brainstormed for ways to spend funds offered in support of initiatives based on the ACRL Strategic Plan. The section is excited to join the College Libraries Section and the Community and Junior College Section in developing a marketing campaign for academic libraries, based in part on materials from the ALA@your library campaign. Currently, ideas include a prototype Web page, a reproducible and customizable brochure, and a poster. Additional information will be available by the ALA Annual Conference in June.
Finally, the Executive Committee continues to explore ways to communicate with section membership. Development of content for the new discussion list is ongoing. Those interested in a low-traffic way to stay in touch with ULS activities are encouraged to join the list. To subscribe, send an e-mail to listproc@alal.ala.org with "subscribe uls-1 your first and last name" in the message field.

\section{Public Services Directors of Large Academic Libraries}

Lucinda Covert Vail (New York University) chaired a well-attended meeting of the ULS Public Services Directors of Large Academic Libraries. Representatives from Association of Research Libraries (ARL) and American Council of Learned Societies (ACLS) were among those attending with project updates.

- Mary Jackson from ARL reported on the status of interlibrary loan and document delivery initiatives, standards development, and upcoming conferences.

- Diane Kresh (head the Library of Congress' Collaborative Digital Reference Services), spoke on the progress being made, including a new agreement with OCLC for delivery of the service. New libraries join

\section{About the author}

Jennifer Evans is collections librarian at Washingtoniana, District of Columbia Public Library, e-mail: rappevans@earthlink.net 


\section{Standards and guidelines feedback needed!}

In 2000, the ACRL University Libraries Section (ULS) appointed a committee to review and update the "Standards for University Libraries," last revised in 1989, and the "Guidelines for Branch Libraries in Colleges and Universities," last revised in 1990. ACRL/ULS Standards/Guidelines Review Committee members are: Lori Goetsch (chair), University of Maryland; Nicholas Burckel, Marquette University; David Lewis, Indiana University-Purdue University, Indianapolis; Louise Sherby, Hunter College, City University of New York; Paula Walker, University of Washington; and Mark Watson, Southern Illinois University.

We need your help! In order to evaluate these documents, the committee needs to know how/if they are used and how they could be made more upto-date and valuable to university libraries.

"Standards for University Libraries" can be found on the ACRL Web page at http://www.ala.org/acrl/guides/

univer.html and were also published in C\&RL News 50, no. 8 (September 1989): 679-91.

"Guidelines for Branch Libraries in

weekly and work continues on developing quality assurance guidelines. The CDRS Web site is http://lcweb.loc.gov/rr/digiref/.

- ServQual/LibQual pilot participants discussed their experiences with using the instrument for measuring service effectiveness at their institutions. Experiences and results varied quite a bit. There will be ARL workshops on LibQual in Washington, D.C. and Seattle this year.

- Hiring, retaining, and working with Generation $\mathrm{X}$ and Generation $\mathrm{Y}$ librarians is an issue of increasing visibility to many participants. Suggestions for retention and working with new librarians were dis-
Colleges and Universities" can be found on the ACRL Web page at http://www. ala.org/acrl/guides/branches.html and were also published in C\&RL News 52, no. 3 (March 1991): 171-74.

Please review each document, then copy and fill out our brief survey on the next page. Send it to Lori A. Goetsch, Public Services, 3115 McKeldin Library, University of Maryland, College Park, MD 20742. Alternatively, you can take the survey on the Web and submit it electronically at http://www.lib.umd.edu/ UMCP/PUB/acrlserv.html.

At the upcoming ALA Conference in San Francisco, the committee will hold an open discussion of the Standards and Guidelines and report on the responses to our survey. Please mark this date on your calendars: Saturday, June 16, 11:30 a.m. (the location will be listed in the conference program under ACRL/ULS Standards/Guidelines Review Committee).

If you have questions or comments and are unable to be at the discussion in San Francisco, please feel free to contact any of the committee members.Lori Goetsch, University of Maryland, lgoetsch@deans.umd.edu

cussed, including sharing expertise and energy and developing cross-mentoring projects.

- Finally, Eileen Gardiner and Ronald Musto spoke about their ACLS History EBook Project forthcoming in the summer of 2001. The project has worked with ten publishers of history books to develop a database of current and backlisted titles of significance to the discipline. Additional information can be found at http:// www.historyEbook.org/.

JoAnne Hawkins (University of Texas at Austin) offered additional perspective (continued on page 408) 


\section{ULS Standards/Guidelines Survey}

1. Please indicate your institution's Carnegie Classification (check one):

Doctoral/Research University - extensive

Doctoral/Research University_intensive

Master's Colleges and Universities I

Master's Colleges and Universities II

Baccalaureate Colleges_-Liberal Arts
-Baccalaureate Colleges-General Baccalaureate/Associate's Colleges

-Associate's Colleges

Specialized Institutions

— Tribal Colleges and Universities

2. Is your library a member of the Association of Research Libraries (ARL)?

Yes

No

3. Have you/your institution ever used the ACRL "Standards for University Libraries?" Yes__ (proceed to question 4)

No___ (proceed to questions 5)

4. If yes, please rank the reasons for your use, with " 1 " being the most important: to support resource/budget requests as a guide/benchmark for library planning required by our institution

- - accreditation/external review

- campus/intemal review

—other please specify:

5. If no, please rank the reasons for your non-use, with " 1 " being the most important: didn't know they were available

- library/institution uses other criteria standards not appropriate/useful for my institution —other—please specify:

6. Have you/your institution ever used the "Guidelines for Branch Libraries in Colleges and Universities?"

Yes__ (proceed to question 7)

No___ (proceed to questions 8)

7. If yes, please rank the reasons for your use, with " 1 " being the most important: to support resource/budget requests as a guide/benchmark for library planning — campus/intemal review required by our institution other-please specify:

8. If no, please rank the reasons for your non-use, with " 1 " being the most important:. didn't know they were available institution uses other criteria standards not appropriate/useful for my institution other-please specify:

9. Given the availability of statistical data from ACRL and ARL, what other quantitative or qualitative measures would be useful to your institution that the standards might be able to provide?

10. What one change would you make to the "Standards for university libraries" to make them more useful/valuable to you?

11. What one change would you make to the "Guidelines for branch libraries in colleges and universities" to make them more useful/valuable to you?

Thank you for assisting us with the process of reviewing these documents! Return (by Wednesday, June 6, 2001) to: Lori Groetsch, Public Services, 3115 McKeldin Library, University of Maryland, College Park, MD 20742. 
(continued from page 406)

on e-books, as they have included this format in their collection planning and online catalog for some time.

\section{Current Topics Discussion Group}

The ULS Current Topics Discussion Group held its traditional Midwinter discussion on the theme "Technology and Librarians: Evolutions of New Roles." The planning committee, chaired by Aline Soules, invited Mary Jane Petrowski (Colgate University) and Karen Williams (University of Arizona) to lead with their personal impressions on the theme.

Petrowski started the session with personal observations on technology's impact on her career and conclusions about working in a world of shifting technologies. She suggested:

- Librarians need to accept responsibility for being lifelong learners of new technologies.

- We should incorporate administrative shifts in our institutions, especially as we add services to faculty grappling with teaching with technology.

- Virtual libraries are overwhelming and often underused, currently.

- Librarians need to model anthropologists and get out to do fieldwork to see how technology is being used.

- The librarian's role as an educator is not diminished, but enhanced by the proliferation of technology.

Karen Williams discussed the many roles librarians are asked to take on at the University of Arizona and at other institutions around the country. We've been asked to:

- negotiate consortial and licensing agreements;

- familiarize ourselves with the nature of copyright and shifting fair use practice;

- develop services to remote users;

- design new instructional models;

- explore scholarly communications; and

- practice knowledge management-a traditional strength; in other words, the ability to get a handle on our institutions' information and call it forward as needed.

Williams offered general themes for discussion as well, including the fact that we are taking on these roles within existing structures. As of yet, there are no standards for how academic libraries are handling new roles. She encouraged participants not to forget changing roles for library staff, in addition to those changes at the librarian or administrative level. Finally, Williams cited a need to draw on other professions for expertise, namely technical and computer professionals, as we expand some services and build new physical and virtual facilities.

The unstructured portion of the discussion began with all of these ideas on the table. Approximately 60 participants engaged with the speakers and with each other. Many picked up on the topic of merging technical staff with librarians, and it was apparent that institutions are grappling with merging computer departments with a variety of library service desks and finding cultural differences to work through. Some institutions are shifting towards fully networked campuses rather than building information commons with merged staff, and again this provides an entirely new set of issues.

Other topics of debate included:

- Taking services out of the building to dorms, commons areas, or wherever the network extends.

- Concerns over staff burnout with the pace of introducing of new skills and technologies. Some institutions have responded with monetary rewards for continual learning, which helps to alleviate some of the stress.

- Significant numbers of institutions are exploring or using Web-based integrated curriculum products and have had many issues arise, including visibility for the library, levels of help and training offered, and exploration for use in library instruction.

- Final topics included a debate over core technical competency for reference staffs, or reliance on students or other staff members for technical assistance.

While conclusions were few, the discussion allowed for a broad exploration of the variety of ways in which librarians interact with and shape technologies. The speakers' thoughtful comments and the exchange that followed provided lots of ideas for further discussion and post-conference follow-up. 


\section{Which of the following services do your users need?}

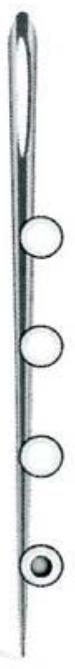

A. Help locating needles in haystacks

B. Help sorting needles according to relevance

C. Access to collections of needles around the world

D. All of the above

Organize, select and describe electronic resources with CORC. The Cooperative Online Resource Catalog makes it possible for libraries around the world to share cataloging and collection development efforts. CORC offers unique tools for metadata harvesting and digital pathfinder creation, designed by and for librarians, to help you gain control over electronic resources. Together, libraries are creating the world's preeminent database of quality, libraryselected electronic resources with CORC.

OCLC CORC-the power of library cooperation at work for you.

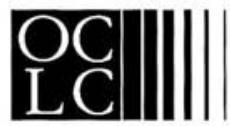

OCLC Online Computer Library Center, Inc. 800.848 .5878 www.oclc.org 


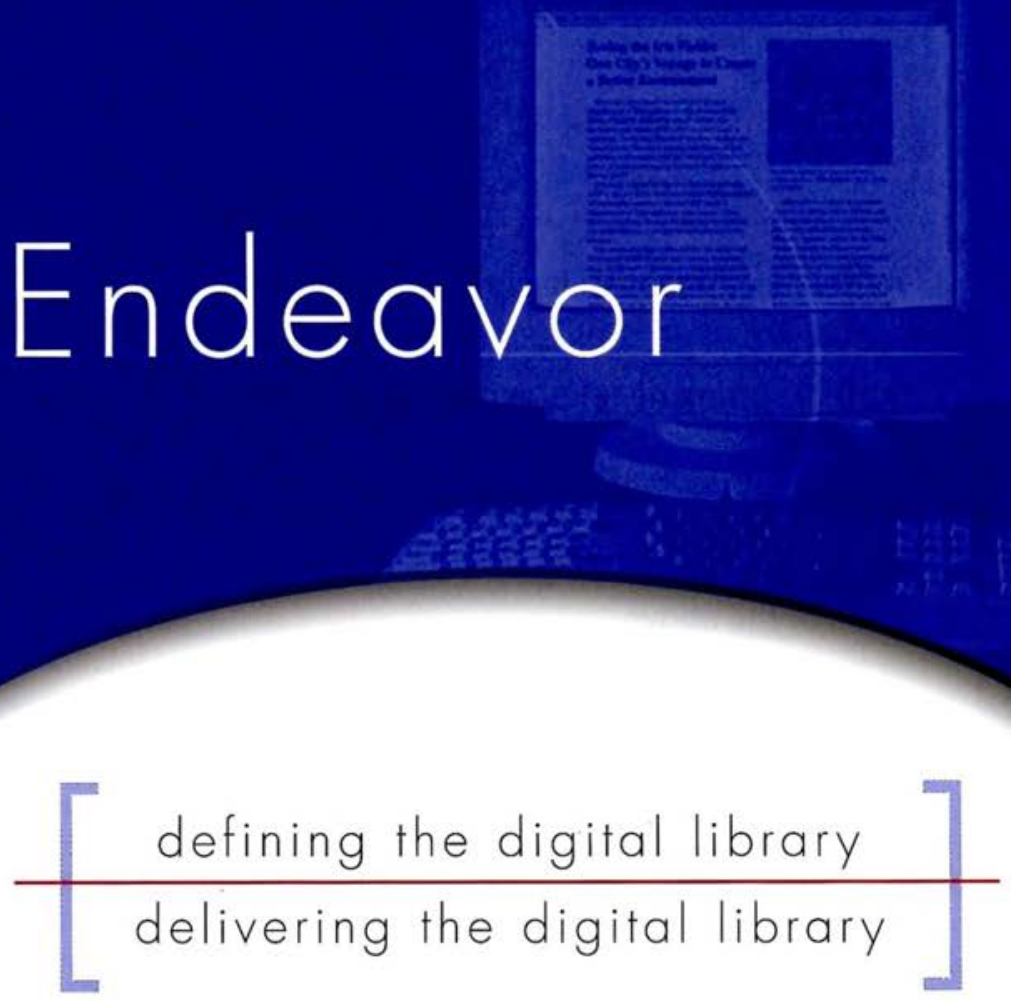

At Endeavor, we do more than just talk about digital libraries. We've defined them. You need integrated access to your local catalog and image, sound and archival collections, combined with content like electronic books and e-journals, all through a single interface. Endeavor's suite of information solutions - Voyager, ImageServer, Citation Server and ENCompass - make the digital library a reality.

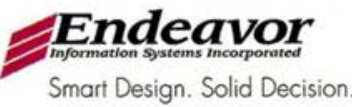

